\title{
PEMBELAJARAN BAHASA ARAB MELALUI KOLABORASI METODE QUESTIONING DAN MEDIA KAHOOT
}

\author{
Ahmad Fadilah Khomsah, Muhammad Imron ${ }^{1 *}$ \\ 1 Pascasarjana UIN Maulana Malik Ibrahim Malang
}

\begin{abstract}
Learning that is conducive and fun in the industrial revolution 4.0 makes changes in learning styles in the learning process. Teachers are asked to follow an interactive digital learning process. Learning that is fun and not boring is one of the challenges for instructors and Developers of Learning Technology to innovate in learning. Questioning method (question and answer) is a method used by teachers in learning to arouse student motivation in expressing opinions in the learning process takes place. In Arabic there are four maharah that must be mastered. To master Arabic, learning media are needed that are effective, efficient and in accordance with the times so that students are interested and enthusiastic in participating in learning activities. However, many teachers are less creative in using existing media. Whereas learning media has a role as an attention drawer, curiosity and facilitates the delivery of information to students. This paper discusses the Collaboration of the Application of Questioning Methods with the Kahoot Application in Arabic Language Learning. Kahoot is one of the learning media in the form of web-based applications for making quizzes and simple games. Teachers as facilitators as well as content creators can add elements in the form of videos, images and texts and students can access them via a smartphone or personal computer.
\end{abstract}

Keywords: Arabic Language, Questioning Method, Kahoot

*Korespondensi Penulis: fadilkhomsah@gmail.com 
Abstrak: Belajar yang kondusif dan menyenangkan dalam revolusi industri 4.0 membuat perubahan gaya belajar dalam proses pembelajaran. Guru diminta untuk mengikuti proses pembelajaran digital interaktif. Belajar yang menyenangkan dan tidak membosankan adalah salah satu tantangan bagi instruktur dan Pengembang Teknologi Pembelajaran untuk berinovasi dalam pembelajaran. Metode tanya jawab (tanya jawab) adalah metode yang digunakan oleh guru dalam pembelajaran untuk membangkitkan motivasi siswa dalam mengungkapkan pendapat dalam proses pembelajaran berlangsung. Dalam bahasa Arab ada empat maharah yang harus dikuasai. Untuk menguasai bahasa Arab, diperlukan media pembelajaran yang efektif, efisien dan sesuai dengan perkembangan zaman sehingga siswa tertarik dan antusias dalam berpartisipasi dalam kegiatan pembelajaran. Namun, banyak guru yang kurang kreatif dalam menggunakan media yang ada. Sedangkan media pembelajaran memiliki peran sebagai pemberi perhatian, keingintahuan dan memfasilitasi penyampaian informasi kepada siswa. Makalah ini membahas Kolaborasi Penerapan Metode Tanya Jawab dengan Aplikasi Kahoot dalam Pembelajaran Bahasa Arab. Kahoot adalah salah satu media pembelajaran dalam bentuk aplikasi berbasis web untuk membuat kuis dan permainan sederhana. Guru sebagai fasilitator serta pembuat konten dapat menambahkan elemen dalam bentuk video, gambar dan teks dan siswa dapat mengaksesnya melalui smartphone atau komputer.

\section{Kata Kunci: Bahasa Arab, Metode Tanya Jawab, Kahoot}

\section{A. Pendahuluan}

Teknik pembelajaran konvensional membuat pelajaran cenderung membosankan, karena nuansa pelajaran yang kurang menarik dan siswa cenderung kesuliatan fokus pada saat pembelajaran berlangsung. Dalam pembelajaran dibutuhkan pengejaran yang kondusif dan menyenangkan terhadap peserta didik agar suapaya tujuan yang diharapkan dalam proses pemelajaran mudah tercapai. Untuk saat ini di era revolusi indrustri 4.0 seluruh perguruan tinggi diharapkan mampu untuk beradaptasi dengan adanya perkembangan teknologi yang sangat pesat, sehingga bisa membantu proses pembelajaran menjadi efektif, menyenangkan dan kondusif. Guru, dosen dan pengembang 
teknologi meliki peran penting dalam dunia pendidikan agar dapat mengembangankan inovasi, ide atau gagasan dengan memamfaatakn teknologi dalam pembelajaran. Keuntungan adanya tekknologi dalam dunia pembelajaran adalah dapat menciptakan nuansa belajar yang efektif dan menyenangkan bagi siswa, dan juga dengan adanya teknologi bisa merangsang siswa dalam latihan, mengerjakan tugas dan bisa menyesuaikan kecepatan belajar yang susai dengan kemampuan siswa hal ini dikemukakan (Made Wena, 2011) dalam jurnalnya.

Kegiatan belajar mengajar yang menyenangkan membutuhkan media berbasis teknologi yang menjadi sarana interaksi di dalam KBM. Proses pembangunan konsep akan mudah dibangun manakala terjadi selain interaksi peserta didik dengan pengajar, namun juga dapat diperoleh melalui interaksi dan komunikasi dengan sumber belajar. Penggunaan teknologi sejatinya sudah berlangsung lama dengan penyampaian informasi yang dapat menunjang pencapaian hasil belajar dengan tentunya memanfaatkan media pembelajaran yang sangat berfungsi dalam membangkitkan semangat belajar yang efektif dan efisien.

Salah satu bentuk pemanfaatan media pembelajaran adalah penggunaan game based learning yang merupakan media yang menggunakan metode berlandaskan permainan yang dapat meningkatkan potensi dan kualitas belajar. Dalam pada itu Dellos juga berpandangan bahwa pembelajaran yang didisain berbasis permainan dapat meningkatkan minat belajar dalam memecahkan persoalan dengan mengedepankan berfikir kritis. Oleh karena itu, media ini sangat tepat untuk diterapkan dalam situasi pembelajaran apapun di dalam kelas.

Pembelajaran bahasa salah satunya diperlukan proses belajar yang menyenangkan dan memotivasi semangat belajar baik secara mandiri maupun berkelompok. Pembelajaran berbasis permainan juga secara implisit mampu mendorong partisipasi peserta didik untuk tidak gagap teknologi serta tidak biasnya dengan lingkungan belajar yang dialaminya. Dalam pada itu, pembelajaran game edukatif juga akan mengajak peserta didik menyalurkan minat yang dimiliki. 
Pembelajaran bahasa Arab yang inovatif memerlukan suasana kondusif, interaktif dan menyenangkan untuk tumbuh kembang peserta didik dalam menerapkan apa yang telah dikuasai. Dalam pada itu, evaluasi pembelajaran juga turut dalam diterapkan melalui media berbasis aplikasi yang perlu digali secara komprehensif. Media Kahoot merupakan salah satu media yang dapat diterapkan dalam pembelajaran bahasa Arab dengan menjadikan belajar menjadi efektif, interaktif, dan menyenangkan karena media ini mengakomodasi gaya belajar mereka dengan keterlibatan aktif dan partisipasi aktif untuk berkomunikasi dengan teman sejawat secara kompetitif. Disamping itu, pembelajaran bahasa Arab dengan Kahoot juga turut serta dalam membangun emosional dan sosial yang dilakukan secara kolaboratif dan partisipasi seluruh elemen peserta didik yang ada di kelas.

Metode pembelajaran Questioning (tanya jawab) dalam pembelajaran bahasa Arab digunakan untuk mengetahui sejauh mana siswa mampu memahami isi materi yang disampaikan oleh guru. Selain dengan bertanya secara langsung guru juga mengkombinasikan dengan sebuah aplikasi yang bernama Kahoot untuk menarik perhatian siswa dan untuk mengukur/ mengevaluasi pemahaman siswa dalam belajar bahasa Arab.

Kegiatan menanya merupakan strategi atau metode dalam pendekatan konstruktivisme untuk mengukur sejauh mana siswa dapat mengenali konsepkonsep pada topik pelajaran yang dipelajari. ${ }^{1}$ Kegiatan menanya dalam sebuah pembelajaran dilihat sebagai kegiatan pendidik untuk mendorong, membimbing, dan menilai kemampuan berpikir peserta didik. Dapat dikatakan bahwa tanya jawab adalah suatu cara penyampaian pelajaran dimana pendidik dan peserta didik aktif, pendidik memberikan peserta didik pertanyan dan peserta didik menjawab atau bisa sebaliknya peserta didik yang bertanya dan pendidik yang menjawab. Kegiatan ini dapat membuat siswa lebih aktif dan dapat mendorong

\footnotetext{
${ }^{1}$ Abuddin Nata, Perspektif Islam Tentang Startegi Pembelajaran, (Jakarta : Kencana, 2009). Hlm. 182
} 
rasa ingin tahu siswa. Kahoot adalah permainan berbasis platform pembelajaran gratis, sebagai teknologi pendidikan yang tersambung dengan internet yang dapat dilakukan secara meriah dan menyenangkan. Dengan demikian, peserta didik tidak merasa bosan dengan dorongan bahwa materi tidaklah sulit untuk dipelajari bahkan membantu untuk memahami dan menerapkan. Oleh karena itu, media ini sangat berpengaruh dengan kekuatan koneksi internet yang cukup untuk dapat dikelola dengan baik. ${ }^{2}$

Mengingat bahwa metode Quesioning jika digabungkan/ dikolaborasikan dengan media Kahoot dalam pembelajaran bahasa Arab akan sangat menarik dan praktis. Disamping itu, pembelajaran menjadi lebih kondusif dan hidup, karena siswa sangat berantusias mengikuti jalannya pembelajaran. Pengkolaborasian media Questioning dengan media Kahoot juga sangat tepat digunakan di era digital seperti ini. Pembelajaran tidak hanya dilakukan di dalam kelas melainkan juga bisa dilkakuan secara Online atau E-Learning yang pastinya bisa menarik antusias siswa dengan pembelajaran semacam ini, karena hal ini merupakan sebuah terobosan baru yang mengkaitkan pembelajaran dengan sebuah aplikasi. Apalagi dengan adanya wabah virus Corona yang mengharuskan siswa belajar di rumah, pembelajaran semacam dirasa juga sangat efektif dan efisien untuk diterapkan.

\section{B. Landasan Teori}

\section{Pembelajaran Bahasa Arab}

Kata pembelajaran diambil dari kata dasarnya yaitu belajar. Belajar sendiri adalah proses berubahnya prilaku individu yang terjadi karena hasil interaksi dengan lingkunganya. Sementara pembelajaran adalah proses mengorganisasi atau mengatur lingkungan yang dapat mendorong peserta didik untuk belajar. Dikatakan pula bahwa pembelajaran adalah proses pemberian wejangan kepada peserta didik agar mampu melakukan proses belajar. (Pane, 2017)

${ }^{2}$ Asuideria, (2018). Manfaat dan Kegunaan Kahoot. Diakses tanggal 19 Mei 2020 pada http://asuiblo.blogspot.com 
Di dalam pembelajaran terdapat proses hubungan antara pendidik dan peserta didik serta hal-hal yang berkaitan seperti bahan pelajaran, sumber belajar, pendekatan belajar, metode, strategi dan hal-hal lain yang dilakukan pada suatu lingkungan belajar dengan harapan bisa mencapai tujuan dari pembelajaran. Adapun salah satu bentuk pembelajaran yang dilakukan baik secara formal maupun non formal adalah pembelajaran bahasa Arab. Bahasa Arab sendiri merupakan satu dari beberapa bahasa asing yang banyak dipelajari di Indonesia. Penduduk Indonesia yang mayoritas muslim menjadi penyebab banyaknya peminat yang ingin belajar dan memahami bahasa Arab serta mampu menggunakannya sebagai alat komunikasi ketika dibutuhkan. Meskipun bahasa Arab tidak digunakan sebagai bahasa utama dalam berkomunikasi pada masyarakat di Indonesia, namun agama islam yang diturunkan dengan wasilah bahasa Arab serta tuntunan ritual ibadah umat islam yang juga menggunakan bahasa Arab menjadi dorongan masyarakat Indonesia untuk mempelajarinya.

Bahasa Arab sendiri merupakan salah satu disiplin ilmu yang terdiri dari berbagai aspek ketrampilan bahasa dan unsur-unsur yang terkandung didalamnya. Pada hakikatnya empat ketrampilan bahasa Arab tidak berbeda dengan keterampilan bahasa lain pada umumnya(Thoha, 2012). Adapun dalam pembelajaran bahasa Arab mencakup 4 kemampuan bahasa yang pertama keterampilan mendengar (al-istima'), kedua keterampilan berbicara (al-kalam), ketiga keterampilan membaca (al-qiro'ah), keempat keterampilan menulis (al-kitabah). ${ }^{3}$

a. Keterampilan mendengar (al-Istima')

Keterampilan mendengar atau yang dalam bahasa Arab disebut Maharah Al-Istima' adalah awal dari ketampilan yang harus dipelajari oleh seseorang yang sedang belajar bahasa. Seorang yang belajar bahasa baik bahasa ibu atau bahasa asing harus menguasai kemampuan mendengar, hal ini tidak terkecuali ketika seseorang belajar bahasa Arab.

${ }^{3}$ As'aril Muhajir. Psikologi Belajar Bahasa Arab. (Jakarta: PT. Bina Ilmu, 2004). Hlm. 15 
b. Keterampilan berbicara (al-Kalâm)

Keterampilan bebicara atau Maharah Al-Kalam merupakan keterampilan kedua sebagai kelanjutan dari keterampilan mendengar. Jika keterampilan mendengar adalah keteampilan yang berkaitan dengan telinga sebagai indra pendengaran, maka keterampilan berbicara adalah keterampilan yang berkaitan dengan lisan sebagai alat untuk berbicara.

Alasan kenapa keterampilan berbicara adalah keterampilan yang harus dikuasai setelah ketrampilan mendengar karena orang yang pendengarannya kurang baik maka akan kesulitan dalam mengucapkan kata-kata melalui lisannya. Bahkan orang yang tidak mampu mendengar maka seseorang tersebut pasti tidak mampu bebicara dengan bahasa yang dapat dipahami oleh orang lain. Pada dasarnya keterampilan berbicara adalah keterampilan mengucapkan apa yang telah didengar dan tersimpan dalam pikiran peserta didik dan diungkapkan dalam bentuk kata-kata yang mampu dipahami oleh orang lain.

c. Keterampilan membaca (al-Qiraah)

Keterampilan membaca atau maharah Al-Qira'ah merupakan keterampilan yang berkaitan dengan pemahaman seseorang terhadap teks tulisan. Kegiatan memahami isi pikiran orang lain yang dituangkan dalam bentuk tulisan tentu berbeda dengan memahami isi pikiran orang lain secara langsung melalui kegiatan berbicara dan mendengar. Hal ini karena ketika seseorang berdialog tidak hanya melibatkan mulutnya saja sebagai tempat keluarnya suara, melainkan terdapat faktor lain yang mampu memberikan pemahaman kepada lawan bicara seperti bahasa tubuh yang ditunjukkan ketika berbicara.(Mustofa, 2012) Keterampilan ini merupakan kemampuan untuk mengenali dan memahami bacaan baik dengan cara melafalkan atau mencernanya dalam hati. 
d. Keterampilan menulis (al-Kitâbah)

Keterampilan menulis atau maharah kitabah merupakan keterampilan tertinggi dari tiga keterampilan bahasa yang lainnya. Banyak yang beranggapan bahwa keterampilan menulis merupakan keterampilan yang paling sulit karena untuk menguasainya seseorang harus mampu menguasai ketrampilan-ketrampilan bahasa yang lain terlebih dahulu. Menulis adalah kegiatan mencurahkan apa yang terdapat dalam pikiran menjadi sebuah tulisan yang dapat dipahami oleh pembaca. ${ }^{4}$

Selain keterampilan bahasa lain, dalam menulis seseorang juga harus memperhatikan aspek-aspek lain seperti penguasaan mufrodat (kosakata), qowaid (tata bahasa), balaghah (sastra) dan pilihan diksi yang tempat. Semua aspek tersebut harus ada ketika seseorang sedang menulis, hal ini karena kegiatan menulis adalah kegiatan yang dituntut untuk memberikan pemahaman orang lain yang tidak sedang berhadapan secara langsung dari apa yang dituliskannya

\section{Konsep Metode Questioning}

Kolaborasi merupakan suatu kerja sama untuk menggapai tujuan dan menempatkan bakat, keahlian, dan kecerdasan untuk bekerja. ${ }^{5}$ Implikasi dari keterampilan Kolaborasi adalah sebuah proses kegiatan belajar mengajar yang memudahkan para peserta didik untuk bekerja sama, saling membimbing, belajar dan berubah bersama, serta maju bersama pula. Inilah yang dibutuhkan dalam menumbuhkan sikap kolaboratif. ketika orang lain yang berbeda dapat belajar untuk berkolaborasi di dalam kelas, Suatu saat mereka diharapkan untuk menjadi warganegara yang lebih baik bagi bangsa dan negaranya, bahkan seluruh dunia.

4 Abdul Wahab Rosyidi dan Mamlu'atul Ni'mah, Memahami Konsep Dasar Pembelajaran Bahasa Arab, (UIN Maliki Press: Malang, 2012). HIm. 83

5 Abdulsyani, Sosiologi Skematika, Teori, dan Terapan, (Jakarta: Bumi Aksara, 1994). Hlm. 156. 
Akan tetapi mereka lebih mudah berinteraksi secara positif dengan orang yang berbeda-beda dalam pola pikirnya.

Kolaborasi metode tanya jawab dengan media aplikasi Kahoot dalam berbagai penelitian membantu efektifitas pembelajaran bahasa Arab terlebih pada keterampilan membaca. Media dia cukup menarik di kalangan peserta didik dengan adanya interaksi dua arah secara interaktif baik antara pendidik dengan peserta didik maupun antara peserta didik dengan pendidik yang dapat memberikan keterangan dan jawaban yang cukup sebagai bentuk evaluasi yang optimal. Ada beberapa pengertian metode ini menurut para ahli diantaranya:

Menurut Roestiyah N. K bahwa metode questioning merupakan sebuah metode pembelajaran yang dilakukan dengan cara memberikan stimulus berupa pertanyaan untuk memberikan modal awal kepada peserta didik dalam mengenali pengetahuan awal. Metode ini dapat meningkatkan motivasi belajar peserta didik dengan lebih mengidentifikasi keadaan sekitar untuk berfikir kritis dan membangun konsep secara utuh dengan pelibatan konteks yang dimiliki oleh peserta didik untuk kemudian diberikan kesempatan untuk memberi tanggapan atau jawaban yang tepat 6

Menurut Drs. Soetomo bahwa metode questioning merupakan sebuah metode pembelajaran yang memfungsikan pertanyaan kepada peserta didik untuk ditemukan jalan keluar atau pemecahan masalah yang dialami untuk kemudian pendidik bersama-sama peserta didik lainnya memberikan jawaban sebagai reaksi nyata tentang kondisi lingkungan sekitar.. ${ }^{7}$

Menurut Syaiful B. Djamarah bahwa metode questioning merupakan metode yang dilakukan dengan cara menyajikan pertanyaan yang wajib dijawab dalam bentuk naratif baik oleh pendidik maupun peserta didik untuk memberikan

\footnotetext{
${ }^{6}$ Roestiyah, N.K, Didaktik Metodik, (Jakarta : PT. Bina Aksara, 1986), hal 70

7 Soetomo, Dasar-dasar interaksi belajar mengajar, (Surabaya : Usaha Nasional, 1993), hal. 148
} 
rangsangan atau stimulus tentang konsep dasar yang dimiliki oleh peserta didik sebelum memasuki materi yang akan dipelajari. ${ }^{8}$

Berdasarkan keterangan di atas, maka metode questioning lebih kepada teknik yang dilakukan secara sistematis dan terarah secara masif dengan fasilitasi yang dilakukan oleh pendidik guna mendapatkan pemahaman baru tentang apa yang ada di sekeliling dengan tindakan respon yang memadai tentang apa yang menjadi kelaziman dalam pemahaman yang dimiliki.

\section{Media Kahoot}

Media merupakan semua bentuk yang dijadikan untuk membawa atau menyampaikan suatu pesan dan ide kepada penerima. Didalam pendidikan, media diartikan sebagai sesuatu yang dapat digunakan dalam mendukung proses pembelajaran yang bertujuan untuk merangsang pikiran serta perasaan peserta didik. Penggunaan media pembelajaran dapat dikelompokkan menjadi tiga bentuk diantaranya media berbasis visual, media berbasis audio dan media yang berbasis dari keduanya yaitu audio visual. Media visual adalah media yang cederung pada aspek penglihatan saja seperti media gambar atau foto, majalah dinding, peta dan lain-lain.

Penggunaan media kahoot dalam pembelajaran juga dapat disandingkan dengan model pembelajaran misalnya media kahoot disandingkan dengan model pembelajaran computer assisted instruction (CIA) dan model - model lainnya(Fitriani et al., 2019). Di sisi lain ada juga model pembelajaran yang membutuhkan bantuan media kahoot misalnya model teknik pembelajaran STAD yang berbantuan dengan media kahoot agar supaya pembelajaran semakin efektif dan juga hasil belajar siswa menjadi semakin baik dan meningkat (Nugraha, 2018).

Kahoot pada hakikatnya merupakan sebuah platform yang menyajikan materi berupa penggabungan proyek atau sering disebut joint project antara

\footnotetext{
8 Syaiful Bahri Djamarah, dkk.,Strategi Belajar Mengajar, (Jakarta: Rineka Cipta , 2006) hal. 107
} 
model Norwegian University of Technology and Science dengan Johan Brand dan Jamie Brooker sebagai pencetus sekaligus perintis media tersebut. Dalam mengoperasikan media Kahoot, perlu dikenali terlebih dahulu domainya yaitu https://kahoots.com untuk para pendidik dan https://kahoot.it untuk para peserta didik. Platform yang diberikan tersebut dapat diakses melalui beragam fitur yang tersedia di dalamnya dengan fasilitas yang free. ${ }^{9}$ Adapun keistimewaan media Kahoot tersebut yaitu dalam menghadirkan kegiatan evaluasi pembelajaran yang disajikan dalam bentuk bermain secara berkelompok maupun secara individu yang wajib terkoneksi dengan sambungan internet, kemudian pelaksanaan pembelajarannya dapat dihubungkan dengan berbagai sumber belajar yang mungkin telah disiapkan terlebih dahulu.

Kahoot juga merupakan aplikasi yang digunakan sebagai media alternatif untuk meningkatan hasil belajar di dalam kelas. Kahoot juga merupaka media interaktif yang dapat menumbuhkan semangat belajar karena dengan adanya inovasi yang menarik dalam aplikasi tersebut (Irwan et al., 2019). Dengan menggunakan media kahoot juga bisa melihat profil minat belajar siswa terhadap pelajaran yang sedang dipelajari dan bisa melihat tingkat hasil belajar siswa semula hasil belajarnya kurang maksimal maka dengan menggunakan media kahoot maka hasil belajarnya menjadi maksimal (Irawati, 2018).

Game kuis dengan menggunakan media kahoot tidak hanya bisa digunakan oleh siswa akan tetapi game ini juga bisa digunakan oleh mahasiswa. Dengan menggunakan game ini dapat mempercepat mahasiswa dalam memahami materi yang telah diajarkan dan juga mahasiswa bisa memantapkan kembali dan berani dalam menyampaikan pendapat materi yang dirasa sangat sulit untuk dipahami (Ningrum, 2018).

${ }^{9}$ Alfred Liubana, Pengertian dan Manfaat Kahoot (2019). Diakses tanggal 19 Mei 2020 pada https://alfredliubana40.wordpress.com 


\section{Metode Penelitian}

Adapun kajian ini menggunakan metode studi literatur yang merupakan kegiatan penelitian yang berfokus kepada pengumpulan data dengan metode pustaka, dengan cara memahami menganalisis dan mencatat. Data yang talah diperoleh kemudian dikelolah menjadi bahan penelitian. Penggunaan motode studi kepustakaan oleh penyusun memiliki tujuan untuk mencari dasar acuan untuk dijadikan sebagai landasan teori dan kerangkah berpikir.

Penulis menggunakan literatur dari berbagai artikel ilmiah, berikut langkah-langkah studi literatur menurut adalah sebagai berikut: 1) Pengumpulan data :diambil dari data sekunder dari beberapa referensi dan literatur yang bersumber dari beberapa buku dan jurnal dan artikel ilmiah yang relevan dengan penelitian, 2) Pengolahan dan Analisis data : Data yang telah diperoleh dari beberapa sumber selanjutnya dikelolah sesuai dengan metode-metode penelitian data yang relevan. Tujuan dari pengelolahan data ini adalah agar data yang telah diperoleh dapat di analisis dengan muda dan disusun salah satu metodologi penelitian.

\section{Hasil Pembahasan}

Era Industri 4.0 merupakan isu terbaru dalam diskusi pembelajaran bahasa arab. bagaimana tidak, hadirnya era tersebut turut serta membawa dampak kepada dunia pembelajaran bahasa arab khususnya (Muhammad, 2018). Dampak tersebut dapat bersifat positif mau pun negatif tergantung dengan penanganannya dan pemanfaatannya.

Pembelajaran yang kondusif dan menyenangkan dalam revolusi industri 4.0 membuat perubahan dalam gaya belajar dalam proses pembelajaran. Guru diminta untuk mengikuti proses pembelajaran digital interaktif. Pembelajaran yang menyenangkan dan tidak membosankan adalah salah satu tantangan bagi instruktur dan Pengembang Teknologi Pembelajaran untuk berinovasi dalam 
pembelajaran. Sudut pandang yang menganggap penggunaan aplikasi berkontribsi dalam praktek pembelajaran secara luas dan tidak terikat kondisi dan situasi. Inovasi pembelajaran interaktif dalam hal ini adalah salah satunya dengan menggunakan Kahoot sebagai media pembelajaran interaktif berbasis pembelajaran berbasis game yang menekankan pada gaya belajar partisipasi aktif semua siswa. Salah satu Platform Kahoot yang digunakan adalah penggunaan kuis online, di mana siswa segera merefleksikan jawaban mereka secara online dan Kahoot mencatat semua kegiatan siswa yang bisa menjadi bahan resume penilaian untuk guru.

Kahoot merupakan media yang menarik yang digunakan dalam pembelajaran yang bisa diaplikasikan pada zaman sekarang yaitu zaman serba digital era revolusi industri 4.0. Media ini juga mengurangi tingkat kebosanan, ketidaktertarikan pada saat pembelajaran. (Surjono, Muhtadi, \& Wahyuningsih, 2017) menyatakan Pemamfaatan media kahoot dalam pembelajaran dapat meningkatkan kualitas isi dalam pembelajaran. Dan teknologi informatika bisa meningkatkan kualitas dan efektifitas pada proses pendidikan.

Ketertarikan peserta didik dalam menggunakan platform Kahoot sebagai kuis dalam pembelajarannya sangatlah tinggi. (Luqman et al., 2017)Agar pembelajaran menjadi bermakna adaalah membuat pembelajaran yang menarik terhadap minta siswa, menyenangkan siswa serta tidak membosankan pada saat pelajaran. (Azhar Arsyad, 2013) Suasana pemeblajaran yang menyenangkan bagi siswa dapat mencurahkan waktu dan perhatiannya secara penuh.

Penggunaan media kahoot memudahkan siswa pada saat pembelajaran dan penggunaan kahoot sebagai kuis pada saat pembelajaran. Perkembangan teknologi yang sangat cepat akan bernilai juga bagi penggunanya jika dapat memud dan aman. (Norhashim, 1996) menyatakan bahwa kriteria dari perangkat lunak pembelajaran yang baik adalah kefleksibel dan mudah .

Mengenai bahasa dalam pemaparan soal kuis yang ditampilkan lewat Kahoot dalam pembelajaran juga turut berpengaruh, meskipun dalam pembuatan 
soal dan jawaban kuis pada aplikasi Kahoot tatanan jumlah hurufnya terbatas. Jadi peran pendidik sebagai konten kreator harus mampu membuat soal dan jawaban kuis dengan sejelas mungkin agar tidak ada kendala ketika peserta didik hendak bermain kuis. (Hamalik, 1994)Media adalah segala sesuatu berupa penyalur pesan yang dapat digunakan dalam proses pembelajaran, yang dapat merangsang pemikiran, minat dan perassan pelajar, peserta didik pada saat kegiatan pembelajaran sedang berlangsung untuk mencapai tujuan pembelajaran. Penilitian ini mennggunakan kahhot sebagai media pembelajaran yang dapat menyalurkan bahan pembelajaran yang bisa dipahami oleh siswa.

Tahap implementasi merupakan tahap penerapannya dalam pembelajaran bahasa Arab dengan menggunakan aplikasi kahoot. Pada tahapan ini akan dipaparkan tentang penggunakan kahoot dalam proses tanya jawab pada pembelajaran khususnya pada pelajaran bahasa. Dari tahapan ini juga kita bisa mengetahui kelebihan dan kekurangan aplikasi kahoot ketika di terapkan pada pembelajaran bahasa Arab.

Kahoot merupakan media yang terdapat pada Era 4.0 sehingga membutuhkan peralatan yang harus dipersiapkan dengan matang. Agar proses evaluasi menggunakan media kahoot mendapatkan hasil yang optimal adapaun pelaratan yang harus diperasiap adalah sebagai berikut:

1. Guru menyiapkan peralatan yang harus dipersiapkan seperti LCD proyektor, laptop dan layar.

2. Bagi siswa diharapkan mebawa Smartphone, tablet atau Laptop.

3. Sekolah bisa menyediakan jaringan internet yang kuat.

Komponen yang harus dilengkapi sebagaimana dijelaskan di atas, dapat diteruskan dengan proses selanjutnya yaitu penyusunan quiz pada konten media Kahoot. Tahapan ini sejatinya memiliki dua metode yang harus diperhatikan yaitu pembuatan item pertanyaan melalui media Kahoot dengan tentunya memanfaatkan smartphone dan perangkat komputer yang telah disiapkan. Adapun penyusunan pertanyaan dengan menggunakan media komputer memiliki 
sedikit perbedaan tahapan atau langkah yang dijelaskan sebagai berikut:: 1) akses terlebih dahulu website kahoot.com dan log in untuk bisa bergabung dan join di dalamnya dengan menggunakan akun gmail atau facebook sebagai tautannya, 2) kliklah quiz untuk memulai membuat soal dengan memilih soal pilihan ganda jika menginginkannya, 3) pertanyaan yang disusun dapat disetting durasi waktunya dengan memberi skor yang sesuai dengan tingkat soal, 4) jika dibutuhkan, dapat diberikan gambar atau video menarik dengan menampilkannya dalam bentuk link, dan 5) agar soal dapat diakses, maka klik copy link untuk menandai proses pembuatan soal telah selesai.

Adapun penggunaan Kahoot untuk kalangan peserta didik tidaklah serumit pendidik, hal dikarenakan mereka hanya menggunakan tanpa terlebih dahulu mendisainnya. Begitu juga mereka tidak perlu mendaftarkan akunnya kecuali diperlukan PIN atau LINK yang diberikan oleh pendidik ketika mendisplau soal tersebut. sementara itu, pengoperasian quiz dilakukan melalui tahap berikut ini: 10

1. Pengoperasian Kahoot oleh guru untuk memulai menampilkan layar dan selanjutnya agar diklik Play sebagai tanda bahwa soal siap didisplay. Kemudian hendaknya memilih mode antara klasik (dilakukan per orang per perangkat) atau tim (per perangkat beberapa orang) sehingga muncul atau keluar menu PIN.

2. Peserta didik dapat mengakses setelah mendapat perintah dari guru dengan mengakses terlebih dahulu website kahoot.it dan join untuk bisa gabung dan memasukkan PINnya masing-masing yang namanya nanti akan muncul di layar monitor.

3. Setelah tahap kedua selesai, maka nama peserta didik akan muncul di layar monitor utama guru kemudian klik mulai untuk menandakan soal telah siap dikerjakan dan pelaksanaan latihan atau tes dapat dimulai.

${ }^{10}$ Aprilia Royana Putri dan Muhammad Alie Muzakki, Implementasi Kahoot sebagai Media Pembelajaran Berbasis Digital Game Based Learning dalam Menghadapi Era Revolusi Industri 4.0, Digital Edumedia Komputindo. (2019) 
Dalam menjalankan media Kahoot, pendidik dapat melakukan variasi dengan terlebih dahulu direncanakan dengan mempertimbangkan penggunaan secara individual ataupun kelompok yang dapat dilakukan kolaborasi model pertanyaan yang didisain untuk tujuan khusus. Tahapan Kolaborasi penggunaan metode tanya jawab dengan media Kahoot dalam pembelajaran bahasa Arab: ${ }^{11}$

1. Guru memberikan sosialisasi terkait penerapan metode tanya jawab dengan media Kahoot dalam pembelajaran bahasa Arab

2. Guru menyiapkan materi sesuai bacaan dengan menyesuaikan bahan ajarnya.

3. Perserta didik (siswa) diberi waktu oleh guru untuk memahami materi yang telah disampaikan

4. Dalam proses belajar guru beberapa kali memberikan pertanyaan terkait pemahaman siswa dalam memahami materi.

5. Kemudian pertanyaan dilanjutkan dengan menggunakan aplikasi Kahoot.

6. Untuk menjalankan aplikasi kahoot pertama-tama guru menyiapkan PIN Kahoot untuk diakses masuk siswa

7. Setelah, semua siswa sudah masuk guru bisa menjalankan aplikasi kahoot.

8. Siswa menjawab setiap soal berdasarkan teks yang sudah dibaca tadi.

9. Setelah semua soal telah diselesaikan guru menampilkan hasil dari soal yang telah dijawab oleh masing-masing siswa.

Dalam pemanfaatan media Kahoot, secara nyata tidak semua sesuai dengan keinginan namun juga terdapat pendidik ataupun bahkan peserta didik yang belum nyaman dengan media ini. Hal ini tidak lepas dari adanya faktor kelebihan dan kekurangan yang dilakukan untuk mengefektifkan proses pembelajaran bahasa Arab. Adapun kelebihan yang dapat dirasakan dalam penggunaan media ini yaitu dapat membantu pendidik dalam mengembangkan pembelajaran berbasis teknologi yang menyajikan permainan yang menyenangkan guna meningkatkan motivasi belajar peserta didik, disamping itu juga pengoperasiannya sungguh

11 Ibid 
mudah dan sederhana untuk dipakai oleh siapapun dengan keperluan pembelajaran dan evaluasi. Media ini lebih bersahabat bagi kalangan peserta didik milenial yang tidak lepas dari gadget yang mendunia di kalangan mereka dan efisiennya yaitu tidak diperlukan menginstal software apapun yang dapat memperberat aplikasi smartphone. Media ini hanya membutuhkan pendaftaran akun facebook ataupun gmail yang sudah lazim dikenali oleh banyak kalangan.

Sebagai user peserta didik hanya menggunakan alamat URL Kahoot.it tanpa harus mendaftarkan akun sendiri, hanya memasukkan PIN yang didapat dari akun guru ketika kahoot di terapkan. Khusus di smarthphone difasilitasi dengan adanya mobile app yang dapat diunduh secara gratis melalui Google Playstore. mobile app untuk memudahkan pembuatan soal dan melakukan modifikasi jika sewaktu - waktu diperlukan perubahan melalui smartphone tanpa harus melalui komputer. Keunggulan lain adalah adanya fitur - fitur analisis evaluasi hasil belajar setiap siswa dan setiap poin soal untuk memudahkan guru membuat analisis dan membuat feedback terhadap hasil belajar. Selain itu media ini juga dapat digunakan sebagai hiburan dalam pembelajaran dan pelatihan.

Kekurangan adanya media kahoot bisa melalui beberapa segi diantaranya segi fasilitas memerlukan koneksi jaringan yang kuat dan kecepatan tinggi, dari segi lingkungan bahwa ada larangan bagi siswa membawa smartphone dan alptop ke sekolah. Untuk saat ini tidak semua peserta didik memiliki smartphonedan laptop bagi orang kaya bisa memilikinya akan tetapi bagi orang yang kekurangan pasti tidak akan memilikinya. Media kahoot juga memerlukan Overhead Projector, LCD proyektor serta listrik yang harus selalu tersedia pada saat proses pembelajaran berlangsung. Ketika salah salah fasilitas tersebut tidak terpenuhi maka media kahoot tidak dapat digunakan atau bisa juga pembelajaran tidak akan efektif.

Faktor-faktor yang dialami oleh berbagai media tidak dapat dipisahkan dari kelebihan dan kekurangan yang hampir pasti tidak ada yang bisa lepas dari semua hal yang dapat menghambat inovasi belajar yang lebih baik dan efektif 
untuk tumbuh kembang pembelajaran bahasa Arab. Kelebihan adalah terkait dengan media kahoot itu sendiri yang meliputi proses pembelajaran atau evaluasi pembelajaran dengan penggunaannya diantaranya: 1) membuat siswa di kelas menjadi aktif, 2) membuat siswa menjadi semangat memperlajari bahasa Arab, 3) membuat siswa lebih mudah dengan materi yang sedang di ajarkan, 4) membuat siswa menjadi termotivasi, 5) membuat siswa menjadi senang dan tidak membosankan ketika pembelajaran berlangsung, 6) guru bisa lebih mudah dalam mengevaluasi siswa pada saat pembelajaran berlangsung dan 7) dengan media ini dapat berkesan kuat terhadap ingat siswa

Disamping adanya kelebihan, rasanya tidak lah pembelajaran berjalan tuntas tanpa adanya kekurangan. Adapun kekurangan penggunaan Kahoot dalam proses pembelajaran atau evaluasi pembelajaran diantaranya:

a. Membuat suasana di kelas menjadi gaduh dan bisa mengganggu kelas lain

b. Membutuhkan waktu yang lumayan banyak karena masih ada persiapan sebelumnya

c. Membutuhkan instrumen atau alat yang lebih.

d. Persiapan dan langkah-langkah yang akan dilaksanakan di harapkan untuk diujicoba terlebih dahulu sebelum diterapkan kepada siswa pada saat pembelajaran.

Dari penjelasan di atas masih banyak kelebihan dan kekurangan media kahoot yang masih belum disebutkan. Setiap media pembelajaran pasti memiliki dampak positif dan negatif dalam penerapannya, untuk itu dengan adanya kelemahan dan kelebihan itu supaya seorang guru bisa memikirkan ulang dalam menggunakan sebuah media pembelajaran lebih - lebih media kahoot. Persiapan demi persiapan yang dilakukan oleh pendidik akan memberikan dampak positif untuk keberlangsungan pembelajaran yang optimal tanpa membutuhkan upaya yang kurang kondusif dalam proses belajar mengajar. 


\section{E. Kesimpulan}

Pembelajaran yang kondusif dan menyenangkan dalam revolusi industri 4.0 membuat perubahan dalam gaya belajar dalam proses pembelajaran. Guru diminta untuk mengikuti proses pembelajaran digital interaktif. Pembelajaran yang inovatif, kreatif menyenangkan dan tidak membosankan merupakan sebuah tantangan bagi instruktur dan Pengembang Teknologi Pembelajaran untuk berinovasi dalam pembelajaran.

Inovasi pembelajaran interaktif dalam hal ini adalah dengan cara menggunakan Kahoot sebagai media pembelajaran yang interaktif berbasis game based learning yang menekankan pada gaya belajar partisipasi aktif semua siswa. Salah satu Platform Kahoot yang digunakan adalah penggunaan kuis online, di mana siswa segera merefleksikan jawaban mereka secara online dan Kahoot mencatat semua kegiatan siswa yang bisa menjadi bahan resume penilaian untuk guru. Dengan menggunakan kahoot dalam proses pembelajar dapat meningkatkan kualitas dari pembelajaran.

\section{Daftar Rujukan}

Abdulsyani, (1994). Sosiologi Skematika, Teori, dan Terapan. Jakarta: Bumi Aksara. Asuideria. (2018). Manfaat dan Kegunaan Kahoot. Diakses tanggal 19 Mei 2020. Pada http://asuiblo.blogspot.com

Charlina, \& Septiyanti. (n.d.). Pemanfaatan Media Kahoot Sebagai Motivasi Belajar Mengikuti Kuis Wacana Bahasa Indonesia.

Djamarah, Syaiful Bahri dkk. (2006). Strategi Belajar Mengajar. Jakarta: Rineka Cipta.

Fitriani, L., Buchori, A., \& Nursyahidah, F. (2019). Pengaruh Penggunaan Media Pembelajaran Kahoot Dengan Model Pembelajaran Computer Assisted Instruction (CAI) terhadap Hasil Belajar Siswa. Senatik, 292-300.

Irma Rasita, \& Soedewo, tatie. (n.d.). Penggunaan Media Kahoot Dalam Pembelajaran Struktur Bahasa Inggris. 
Irawati, M. (2018). Profil Minat dan Hasil Belajar Siswa Dalam Pembelajaran Matematika Kelas VII I SMP Negeri 5 Yogyakarta Dengan Menggunakan Media Pembelajaran Kahoot. Yogyakarta: Universitas Sanata Dharma.

Irwan, I., Luthfi, Z. F., \& Waldi, A. (2019). Efektifitas Penggunaan Kahoot! Untuk meningkatkan hasil belajar siswa [Effectiveness of using Kahoot! To improve student learning outcomes]. Pedagogia: Jurnal Pendidikan, 8(1), 95-104.

Liubana, Alfred. (2019). Pengertian dan Manfaat Kahoot. Diakses tanggal 19 Mei 2020 pada https://alfredliubana40.wordpress.com

Muhajir, As'aril. (2004). Psikologi Belajar Bahasa Arab. Jakarta : PT. Bina Ilmu.

Nata, Abuddin, (2009). Perspektif Islam Tentang Startegi Pembelajaran. Jakarta : Kencana.

Ningrum, G. D. K. (2018). Studi Penerapan Media Kuis Interaktif Berbasis Game Edukasi Kahoot! Terhadap Hasil Belajar Mahasiswa. VOX Edukasia: Jurnal Ilmiah Ilmu Pendidikan, 9(1), 22-27.

Nugraha, H. (2018). Meningkatkan pemahaman Matematika Siswa SMP Negeri 1 Pagaden Kelas VIII dengan Gamification Kahoot. UJMES (Uninus Journal of Mathematics Education and Science), 3(1), 148-154.

Putri, Aprilia Royana dan Muhammad Alie Muzakki. (2019). Implementasi Kahoot sebagai Media Pembelajaran Berbasis Digital Game Based Learning dalam Menghadapi Era Revolusi Industri 4.0. Jakarta: Digital Edumedia Komputindo

Roestiyah, N.K, (1986). Didaktik Metodik. Jakarta : PT. Bina Aksara.

Rosyidi, Abdul Wahab dan Mamlu'atul Ni'mah. (2012). Memahami Konsep Dasar Pembelajaran Bahasa Arab. Malang : UIN Maliki Press.

Setiawan, H. desi, Sihkabuden, \& Adi, E. Pramono. (n.d.). Pengaruh Kahoot Terhadap Hasil Belajar Siswa Kelas XI Di SMAN 1 Blitar.

Soetomo. (1993). Dasar-dasar Interaksi Belajar Mengajar. Surabaya : Usaha Nasional. 